\title{
Numerical modelling of the impact of wildland- urban interface fires on Coimbra air quality
}

\author{
A. I. Miranda, J. H. Amorim, V. Martins, C. Pimentel, \\ R. Rodrigues, R. Tavares \& C. Borrego \\ CESAM \& Department of Environment and Planning, \\ University of Aveiro, Portugal
}

\begin{abstract}
Forest fires are a major emission source of pollutants to the atmosphere with several adverse impacts on human health and ecosystems either at local, regional or global scales. Entire populations can be exposed to hazardous concentrations of toxins, especially when fire occurs in the vicinity of cities, as recently drawn by large wildfires in Southeast Asia, Australia, South America or Russia, but also Southern Europe, namely in Portugal. Nowadays there is a growing concern about the increase in both the frequency and the severity of forest fires spreading in the urban wildland interface (WUI) as a consequence of the escalation of urban development among or adjacent to wildlands. The main purpose of this paper is to estimate the impact of wildland forest fires on the air quality of a city in Portugal. Aiming to take into account the effect of a larger atmospheric scale in the very local urban one, a multi-scale approach was adopted, which implied the link between a chemistry-transport mesoscale model (LOTOS-EUROS) and a microscale computational fluid dynamics (CFD) model. Forest fire emissions were estimated based on specific southern European emission factors, type of vegetation, area burned and fire behaviour, and were incorporated in the emission input data of the numerical modelling system. Results confirm the strong impact of forest fires on the urban air pollution levels. Statistical indicators were used to validate the modelling application through the comparison of results to measured air quality data. This modelling approach has got very good performance skills showing the possibility of applying this kind of system to analyse the relation between forest fires and urban air pollution.
\end{abstract}

Keywords: smoke, forest fires, wildland urban interface, numerical modelling, multi-scale, urban air quality. 


\section{Introduction}

Smoke has to be considered as one of the several disturbing effects of forest fires. Its impacts on air quality and human health can be important since large amounts of pollutants, like particulate matter (PM), carbon monoxide (CO), volatile organic compounds (VOC) and nitrogen oxides $\left(\mathrm{NO}_{\mathrm{x}}\right)$, are emitted to the atmosphere [1-5]. The acute air pollution episodes caused by fires in Amazonia, Indonesia and Philippines in 1997, drawn worldwide attention to the problem. The effects of these emissions are felt at different levels: from the contribution to global climate change to the occurrence of local atmospheric pollution episodes [6-8]. Currently, there is a growing awareness that smoke from wildland fires can expose individuals and populations to hazardous air pollutants. The World Health Organization (WHO) has even provided guidelines for forest fire episodic events to protect the public from adverse health effects [9], particularly in the wildland urban interface (WUI) due to the highest risk of human exposure.

The study of smoke dispersion and chemistry in the analysis of WUI fires is a vital task in order to prevent the exposure of population to hazardous concentrations of air pollutants. The "Black Christmas" bushfires in $2001-2002$ in New South Wales, Sydney, is an example of a WUI which impact was largely known due to its dimension. This disaster "surrounded Sydney in a ring of flames" and clouded the city in a haze of smoke [10]. In southern Europe several cities have been affected by air pollution episodes resulting from forest fires occurrences. In the summer of 1997 the city of Marseille, France, experienced an important air quality problem mainly related to the forest fires spreading at the Étoile Mountain [7]. Athens is another city that has been facing several air quality problems related to forest fires emissions. In Portugal, the summer of 2003 was considered the most devastating of the last decade in terms of forest fires, and this is clearly reflected in the values measured by the air qualitymonitoring networks [11]. Several air quality stations registered extremely high pollutant concentrations due to fire emissions and transport from surrounding areas. Also more than one thousand people (mainly civilian) needing medical assistance due to smoke intoxications, burns and wounds from forest fires in Portugal were reported [12].

Smoke dispersion numerical modelling allows the understanding of how pollutants emitted by a forest fire will be transported, dispersed, and will suffer chemical transformations in the atmosphere, estimating the resulting air pollutants concentration fields. Several studies have been addressing the problematic of smoke transport along wide regions in the globe and its impacts in hemispheric emissions $[13,14]$. On the other hand, there are some modelling systems aiming to simulate forest fires effects on air quality [15-17] in order to better understand and predict potential consequences namely on human exposure, air quality management strategies and international policy commitments.

This paper aims to estimate the effects of WUI forest fires on the air quality of a Portuguese city through the application of a multi-scale modelling system, 
and also to evaluate its performance comparing results with air pollutants concentration measured values.

\section{The modelling approach}

Aiming to capture the effects of larger atmospheric scale on the smaller one a multi-scale approach was adopted for the evaluation of the impact on air quality of forest fires spreading in a WUI. Thus a mesoscale air quality model, LOTOSEUROS, was applied to a larger area with a coarser spatial resolution. Thereafter its air quality estimates were used as boundary conditions to a CFD model, FLUENT, which was applied to an area in the centre of the city with a much higher spatial resolution.

\subsection{LOTOS-EUROS}

The LOTOS-EUROS model [18] is a mesoscale chemistry transport model (CTM). It includes the ozone $\left(\mathrm{O}_{3}\right)$ chemistry using a modified CBM4 mechanism and incorporates primary particles (elemental carbon and organic carbon), sea salt and secondary inorganic aerosols. Crustal matter and secondary organic aerosols are not incorporated. In the vertical the model has four layers up to $3,500 \mathrm{~m}$ following the dynamic mixing layer approach. It was applied first at a continental scale (with $35 \times 25 \mathrm{~km}^{2}$ resolution) and then to mainland Portugal domain, using the same physics and a one-way nesting technique, with $17.5 \mathrm{x}$ $12.5 \mathrm{~km}^{2}$ horizontal resolution. Hence, the option to zoom in a factor of 2 over Portugal using a one-way nest with boundary conditions obtained from simulation over the full domain was used. Anthropogenic emissions were obtained from a Europe wide emission inventory made at TNO [18]. For a detailed discussion on the model performance for $\mathrm{PM}, \mathrm{O}_{3}$, and its components (see Schaap et al. [18]).

\subsection{FLUENT}

The commercial CFD (Computational Fluid Dynamics) model FLUENT (v. 6.1.18 for UNIX platforms) was used as the local scale model. The application of this tool with complex urban environments was validated by the authors in previous works $[19,20]$. The flow and dispersion fields were modelled with an Eulerian approach, using the $k-\varepsilon$ turbulence model.

\section{Case study}

Like the 2003 fire season, the 2005 season also was a critical one, with a huge number of wild fires burning forested areas in Portugal. In August 2005 several forest fires have been spreading in the vicinity of Coimbra. Coimbra is one of the most important urban centers of Portugal after the much larger Lisbon Metropolitan Area and Porto Metropolitan Area conurbations, and plays a role as the chief urban centre of the central part of the country. Over 430,000 inhabitants 
live in the Greater Metropolitan Area of Coimbra (GMAC) made of 16 municipalities comprising a $3,372 \mathrm{~km}^{2}$ territory.

At the end of August, particularly in 21 and 22, Coimbra suffered the effects of smoke from WUI forest fires. The urban air quality monitoring network registered the impact of this smoke on the concentration values. Figure 1 shows the extensive area burned near the city limits of Coimbra.

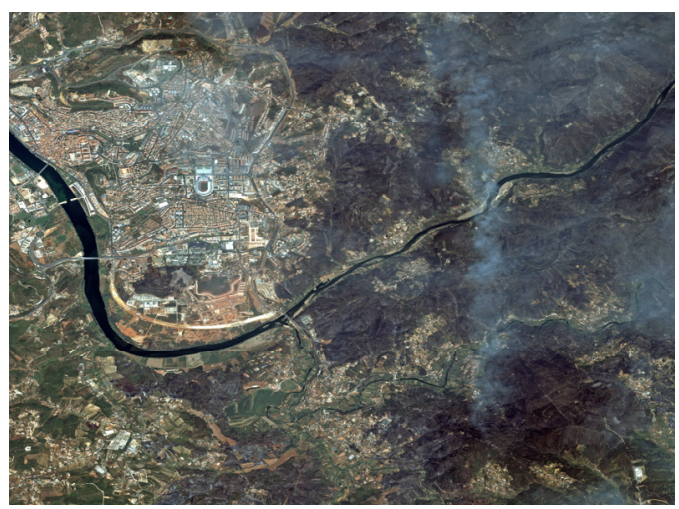

Figure 1: Satellite image from the $24^{\text {th }}$ of August 2005 showing the extensive area burned near the city limits of Coimbra [21].

Because of its urban/wildland characteristics, high population density, and hence higher risk of human exposure to smoke, and the high levels of pollutants registered, Coimbra forest fires are a very interesting case for the study of the influence of forest fires emissions on air quality.

\subsection{Forest fire emissions}

Along 21 and 22 of August 2005 three major forest fires were spreading in GMAC, burning a total area of 6,000 ha. Table 1 presents the main characteristics of these fires.

Table 1: Data concerning the WUI forest fires in Coimbra.

\begin{tabular}{ccccccccc}
\hline \multirow{2}{*}{ District } & \multirow{2}{*}{ Location } & \multicolumn{2}{c}{ Ignition point } & \multicolumn{2}{c}{ Alert } & \multicolumn{2}{c}{ Extinction } & \multicolumn{2}{c}{$\begin{array}{c}\text { Area } \\
\text { burnt } \\
\end{array}$} \\
& Lat $\left({ }^{\circ}\right)$ & Lon $\left({ }^{\circ}\right)$ & Date & Time & Date & Time & (ha) \\
\hline \multirow{3}{*}{ Coimbra } & Coimbra & 40.183 & -8.353 & $21-08-2005$ & $17: 10$ & $27-08-2005$ & $12: 00$ & 3,773 \\
\cline { 2 - 9 } & Poiares & 40.230 & -8.305 & $21-08-2005$ & $13: 45$ & $24-08-2005$ & $13: 00$ & 1,835 \\
\cline { 2 - 9 } & Penacova & 40.296 & -8.210 & $22-08-2005$ & $13: 02$ & $22-08-2005$ & $13: 59$ & 494 \\
\hline
\end{tabular}

Emissions from these forest fires have been estimated using a simple methodology, which includes emission factors, burning efficiency, fuel loads and area burned:

$$
E_{i}=A \times B \times \beta \times F E_{i}
$$


in which: A - available fuel area $\left(\mathrm{m}^{2}\right) ; \mathrm{B}$ - fuel load $\left(\mathrm{kg} \mathrm{m}^{-2}\right) ; \beta$ - burning efficiency; $\mathrm{FE}_{\mathrm{i}}$ - emission factor for pollutant $\mathrm{i}\left(\mathrm{g} \mathrm{kg}^{-1}\right)$; and $\mathrm{E}_{\mathrm{i}}-$ emissions for pollutant i (g).

Specific values for Portugal were selected based on data from the National Forest Inventory, on the characteristics of the consumed forest type and shrubs, and fire data like ignition point and time and area burned. Emission factors for $\mathrm{CO}$, methane $\left(\mathrm{CH}_{4}\right)$, non-methane hydrocarbons (NMHC), $\mathrm{PM}_{2.5}, \mathrm{PM}_{10}$, and $\mathrm{NO}_{\mathrm{x}}$ came from a bibliographic review that allowed to select the most suitable for south European ecosystems, namely for the Portuguese land use types [16]. Table 2 shows the estimated emission values for each fire and each pollutant.

Table 2: $\quad$ Averaged hourly emission rates for the WUI forest fires (ton $\mathrm{h}^{-1}$ ).

\begin{tabular}{lcccccc}
\hline \multirow{2}{*}{ Location } & \multicolumn{7}{c}{ Emission rate $\left(\right.$ ton $\left.^{-1}\right)$} \\
\cline { 2 - 7 } & $\mathrm{PM}_{10}$ & $\mathrm{CO}$ & $\mathrm{NO}_{\mathrm{x}}$ & $\mathrm{NMHC}$ & $\mathrm{CH}_{4}$ & $\mathrm{PM}_{2.5}$ \\
\hline Coimbra & 8.266 & 75.198 & 3.198 & 4.951 & 3.763 & 7.224 \\
\hline Poiares & 5.666 & 51.982 & 2.097 & 3.244 & 2.606 & 4.938 \\
\hline Penacova & 1.203 & 11.321 & 0.335 & 0.595 & 0.571 & 1.041 \\
\hline
\end{tabular}

These emission rate values were given as input data to LOTOS-EUROS. A typical profile of hourly spreading of forest fires along a day was used to estimate the hourly variability of burned area for the period under analysis.

\subsection{Air quality simulations}

Both air quality models were applied on a hourly basis for the estimation of the following air pollutants concentrations: $\mathrm{PM}_{10}, \mathrm{NO}_{2}$ and $\mathrm{O}_{3}$, in the period from 1 p.m. on the $21^{\text {st }}$ to 1 p.m. on the $22^{\text {nd }}$ of August 2005. For each of the considered pollutants, concentration values resulting from LOTOS-EUROS application were defined at the inflow boundaries of the local scale domain.

The selected local scale simulation domain (see Figure 2), comprises an area of $1 \mathrm{~km}^{2}$, and it is centred at the main "Fernão de Magalhães" Avenue, in the downtown of Coimbra. Beyond the highly geometrical complexity of the buildings, the domain is also characterised by a small hill located at NE. The mesh was generated using an unstructured scheme, resulting on a total of more than 1.2 million computational cells.

The model considers also the local contribution of road traffic emissions to the overall air quality. Therefore, the hourly mean values of traffic emissions for $\mathrm{PM}_{10}$, NO and $\mathrm{NO}_{2}$ were estimated through the application of the Transport Emission Model for Line Sources (TREM) [19].

Meteorological parameters were measured in a nearby mast. Very low wind velocities and significant variation of wind direction, as expected in nearly calm wind conditions, contributed to the high concentrations registered. 


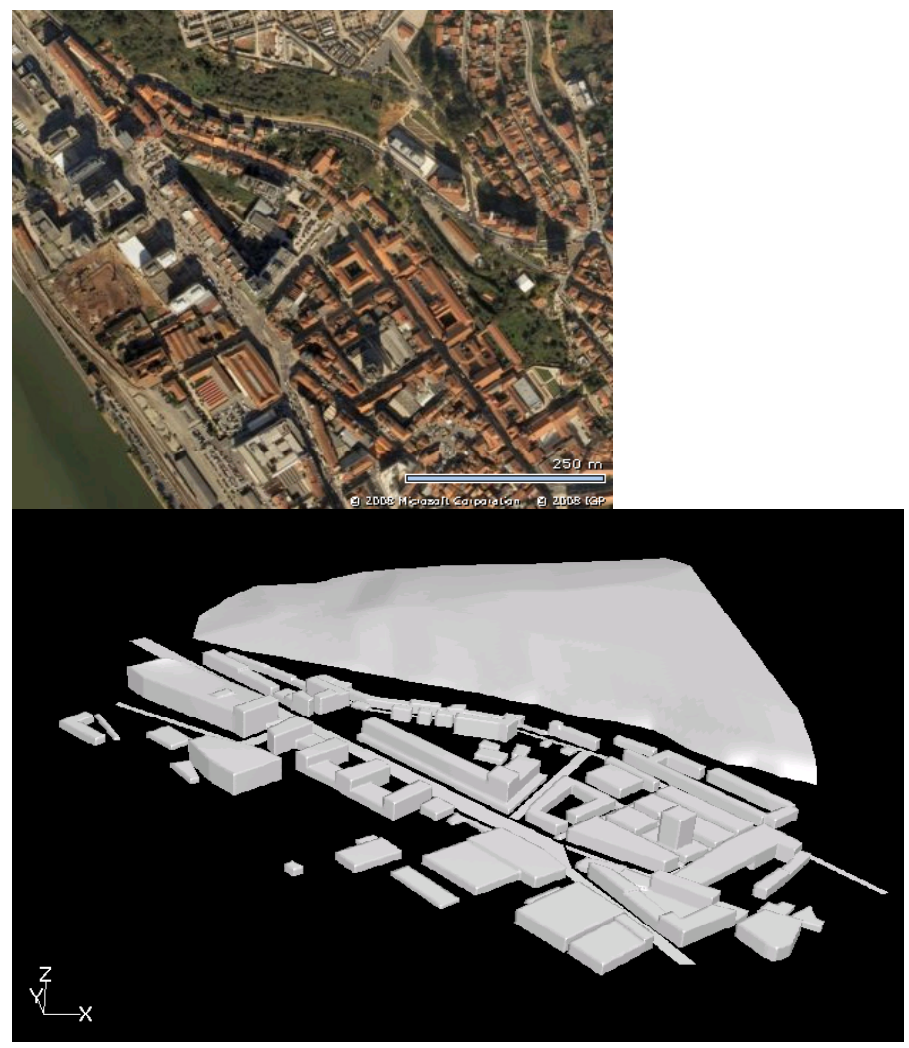

Figure 2: Aerial image of the simulation domain [22] and 3D geometry generated by the model.

\section{Results}

In Figure 3, an example of a $\mathrm{PM}_{10}$ concentration field for the most critical period in terms of air quality is shown. For this particular hour wind was blowing from the fire area towards the city.

The spatial distribution of $\mathrm{PM}_{10}$ shows high values of concentration, surpassing the $400 \mu \mathrm{g} \mathrm{m}^{-3}$ within the entire local scale domain, which is a result of forest fire effects on the local scale air quality. Due to this, the hot-spots resulting from road traffic emissions typically found along the Avenue are "diluted" by the much higher concentration levels contained in the smoke from biomass burning.

Figure 4 presents a similar result, but for the $1^{\text {st }}$ day of simulation (21 August) at 11 p.m. The wind wasn't coming from the fire area and hence concentration values are not so high as before and it is possible to identify the typical urban hot-spot in the city centre. 


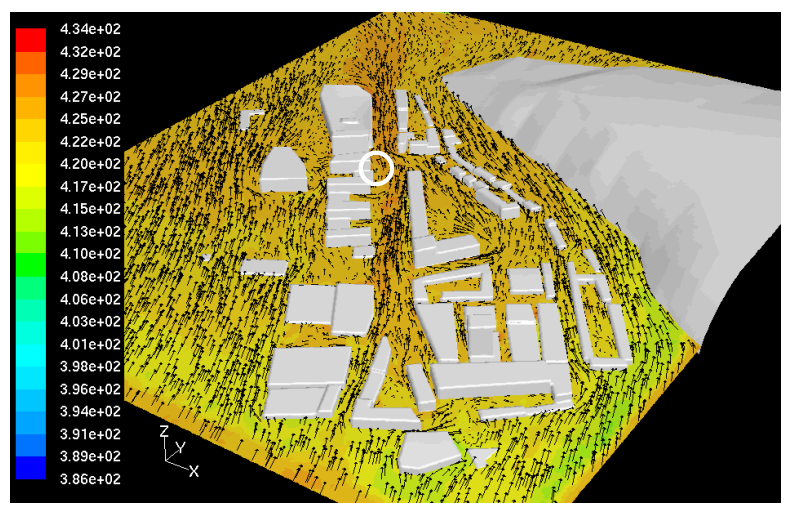

Figure 3: $\quad$ Simulated $\mathrm{PM}_{10}$ concentration $\left(\mu \mathrm{g} \mathrm{m}^{-3}\right)$ horizontal field $(7 \mathrm{~m}$ high $)$ at 11 a.m., 22 August 2005. The location of the air quality station is represented by the white circle. Arrows indicate the wind flow.

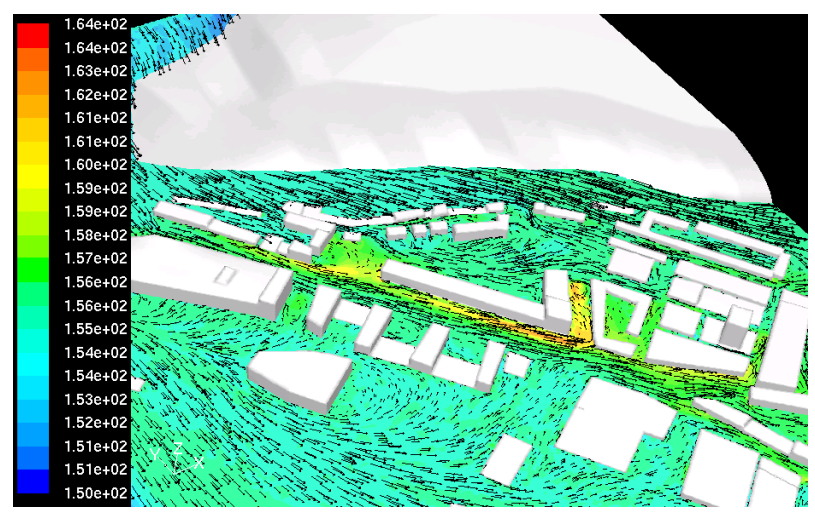

Figure 4: $\quad$ Simulated $\mathrm{PM}_{10}$ concentration $\left(\mu \mathrm{g} \mathrm{m}^{-3}\right)$ horizontal field $(7 \mathrm{~m}$ high $)$ at 11 p.m., 21 August 2005. Arrows indicate the wind flow.

The availability of air quality data from a monitoring station classified as traffic type, located inside the local scale domain, allowed evaluating the performance of the used modelling approach. The temporal variation of the hourly averaged values $\left(\mu \mathrm{g} \mathrm{m}^{-3}\right)$ of simulated and measured concentrations of $\mathrm{PM}_{10}, \mathrm{NO}_{2}$ and $\mathrm{O}_{3}$ is presented in Figure 4.

When comparing to measurements the model has a generally good performance, accompanying the evolution of the concentrations during all the period under study. A difficulty in dealing with the $\mathrm{O}_{3}$ concentration peak at 16:00 and with the critical $\mathrm{PM}_{10}$ peak $\left(584 \mu \mathrm{g} \mathrm{m}^{-3}\right)$ at 9:00 is noticed.

Moreover some statistical parameters were used to evaluate the simulation results: root mean square error (RMSE), systematic error (BIAS) and correlation coefficient (r). Table 3 presents the statistical analysis for hourly averaged $\mathrm{PM}_{10}$, $\mathrm{NO}_{2}$ and $\mathrm{O}_{3}$. 


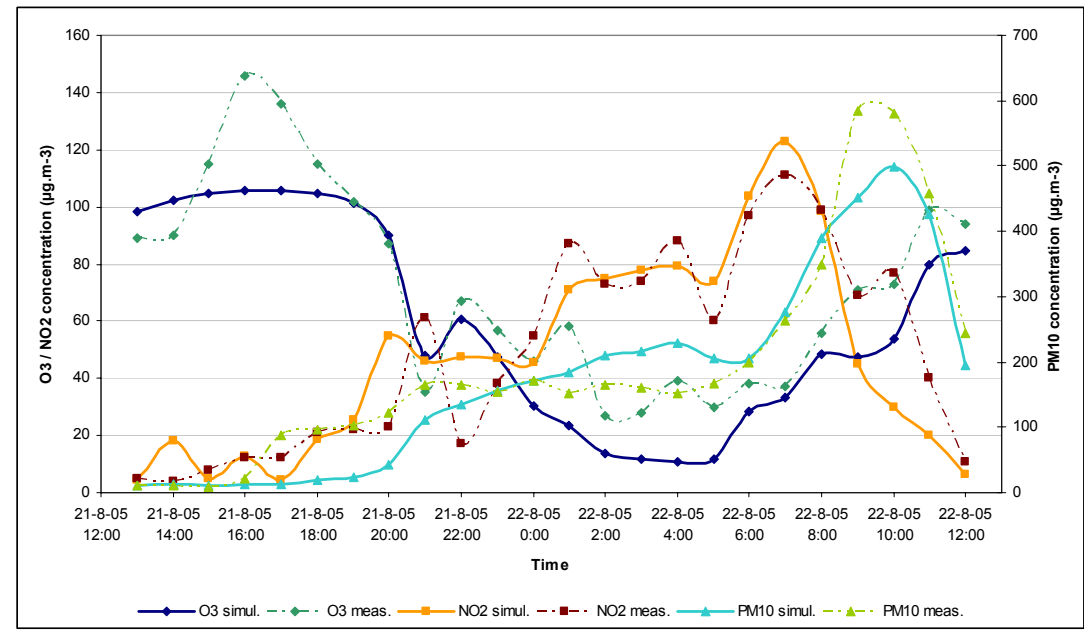

Figure 5: Time evolution of the hourly averaged values of simulated and measured $\mathrm{PM}_{10}, \mathrm{NO}_{2}$ and $\mathrm{O}_{3}$ concentrations $\left(\mu \mathrm{g} \mathrm{m}^{-3}\right)$.

Table 3: $\quad$ Statistical analysis of the modelling results.

\begin{tabular}{lccc}
\hline Parameters & $\mathrm{O}_{3}$ & $\mathrm{NO}_{2}$ & $\mathrm{PM}_{10}$ \\
\hline $\operatorname{RMSE}\left(\mu \mathrm{g} \mathrm{m}^{-3}\right)$ & 3.69 & 3.38 & 11.10 \\
\hline $\operatorname{BIAS}\left(\mu \mathrm{g} \mathrm{m}^{-3}\right)$ & -12.02 & -1.36 & -16.09 \\
\hline $\mathrm{r}(\%)$ & 92 & 88 & 94 \\
\hline
\end{tabular}

The estimated statistical parameters show the good performance of the system. RMSE is very low and the correlation coefficient high. BIAS indicates an underestimation of the model for the three pollutants.

\section{Conclusions}

Only using the multi-scale approach was possible to simulate the effects of the WUI forest fires at the Coimbra downtown with such a detailed estimation. In fact, the simulation with the mesoscale model LOTOS-EUROS is too coarse to capture the local features of air pollution within the city centre. On the other side, the WUI fires were spreading outside the city and with a local scale model, as the used CFD, is currently impossible to simulate such a large domain that includes the burned area and the city centre. Thus, the link between the two models seems a good way to take into account fire emissions on the local urban air quality, through the use of the mesoscale CTM results as boundary conditions to the local CFD model.

Notwithstanding all the uncertainties associated to this kind of work, namely those concerning forest fire emissions, the comparison between simulated values and measured ones highlights this multi-scale approach added value, with a good performance of the system. 
Finally taking into consideration that our main goal is to prevent human health effects associated to forest fire emissions, the possibility to go deeper in the estimation of urban areas hotspots affected by WUI forest fires could be a clear advance towards a more efficient air quality management.

\section{Acknowledgements}

The authors thank the Portuguese Foundation for Science and Technology for the Ph.D. grants of J.H. Amorim (SFRH/BD/11044/2002) and V. Martins (SFRH/BD/39799/2007) and for the Project INTERFACE (POCI/AMB/60660/2004 in the scope of FEDER European funds).

\section{References}

[1] Ward, D., Rothermel, R. \& Bushey, C., Particulate Matter and Trace Gas Emissions from the Canyon Creek Fire of 1988. Proceedings of the 12th Fire and Forest Meteorology, eds. Society of American Foresters, pp. 6276, 1993.

[2] Miranda, A.I., Borrego, C. \& Viegas, D. Forest fire effects on the air quality. Proceedings of the Second International Conference on Air Pollution, Vol. 1: Computer Simulation, eds. J. Baldasano, C. Brebbia, H. Power \& P. Zannetti, Computational Mechanics Publications: Southampton, pp. 191-199, 1994.

[3] Reinhardt, E., Ottmar, R. \& Castilla, C., Smoke Impacts from Agricultural Burning in a Rural Brazilian Town. Journal of the Air \& Waste Management Association, 51, pp. 443-450, 2001.

[4] Miranda, A.I. \& Borrego, C. Air quality measurements during prescribed fires. Proceedings of the IV International Conference on Forest Fire Research - Forest Fire Research \& Wildland Fire Safety, eds. D.X. Viegas, Milpress: Rotterdam, pp. 205, 2002.

[5] Miranda, A.I., Ferreira, J., Valente, J., Santos, P., Amorim, J.H. \& Borrego, C., Smoke measurements during Gestosa 2002 experimental field fires. International Journal of Wildland Fire, 14, pp. 107-116, 2005.

[6] Miranda, A.I., Coutinho, M. \& Borrego, C., Forest fires emissions in Portugal: a contribution to global warming? Environmental Pollution, 83, pp. 121-123, 1994.

[7] Borrego, C., Miranda, A.I., Carvalho, A.C, \& Carvalho, A., Forest fires and air pollution: A local and a global perspective. Proceedings of the Air Pollution VII, eds. C. Brebbia, M. Jacobson \& H. Power, WIT Press: Boston, pp. 741-750, 1999.

[8] Simmonds, P.G., Manning, A.J., Derwent, R.G., Ciais, P., Ramonet, M., Kazan, V. \& Ryall, D., A burning question. Can recent growth rate anomalies in the greenhouse gases be attributed to large-scale biomass burning events? Atmospheric Environment, 39, pp. 2513-2517, 2005. 
[9] Schwela, D., Goldammer, J., Morawska, L. \& Simpson, O., Health guidelines for vegetation fire events, World Health Organization: Geneva, 1999.

[10] Coghlan, B., The human health impact of the 2001-2002 "Black Christmas" bushfires in New South Wales, Australia: an alternative multidisciplinary strategy. Journal of Rural and Remote Environmental Health, 3(1), pp. $18-$ 28, 2004.

[11] Miranda, A.I., Martins, H., Carvalho, A. \& Borrego, C., Modelling Smoke Effects on Lisbon Air Quality. Sixth Fire and Forest Meteorology Symposium and the $19^{\text {th }}$ Interior West Fire Council Meeting, Proceedings in CD-Rom, 2005.

[12] European Commission, Forest Fires in Europe - 2003 Fire Campaign, Official Publication of the European Communities, SPI.04.124 EN, 2004.

[13] Freitas, S.R., Longo, K., Dias, M., Dias, P., Chatfield, R., Prins, E., Artaxo, P., Grell, G. \& Recuero, F., Monitoring the Transport of Biomass Burning Emissions in South America. Environmental Fluid Mechanics, 5, pp. 135$167,2005$.

[14] Wang, J., Christopher, S.A., Nair, U.S., Reid, J.S., Prins, E.M., Szykman, J. \& Hand, J.L., Mesoscale modeling of Central American smoke transport to the United States: 1. "Top-down" assessment of emission strength and diurnal variation impacts. Journal of Geophysical Research, 111, 2006.

[15] O’Neill, S., Ferguson, S., Peterson, J. \& Wilson, R., The BlueSky smoke modelling framework. Proceedings of he ' $5^{\text {th }}$ Symposium on Fire and Forest Meteorology, eds. American Meteorological Society, 2003.

[16] Miranda, A.I., An integrated numerical system to estimate air quality effects of forest fires. International Journal of Wildland Fire, 10, pp. 217 226, 2004.

[17] Liu, Y., Achtemeier, G. \& Goodrick, S., Air quality effects of prescribed fires simulated with CMAQ. The Third Models-3 Workshop, Chapel Hill: NC, pp. 1-4., 2004

[18] Schaap, M., Timmermans, R.M., Sauter, F.J., Roemer, M., Velders, G.J., Boersen, G.A., Beck, J.P. \& Builtjes, P., The LOTOS-EUROS model: description, validation and latest developments. Int. J. Environ. Pollut., 32(2), pp. $270-290,2008$.

[19] Borrego, C., Tchepel, O., Costa, A.M., Amorim, J.H. \& Miranda, A.I., Emission and dispersion modelling of Lisbon air quality at local scale. Atmospheric Environment, 37, pp. 5197-5205, 2003.

[20] Borrego, C., Tchepel, O., Salmim, L., Amorim, J.H., Costa, A.M. \& Janko, J., Integrated modelling of road traffic emissions: application to Lisbon air quality management. Cybernetics and Systems: An International Journal, 35 (5-6), pp. 535-548, 2004.

[21] http://www.euspaceimaging.com/

[22] http://maps.live.com/ 